\title{
PReS-FINAL-2143: Treat-to-target strategy in juvenile idiopathic arthritis: experience in 175 newly-diagnosed patients
}

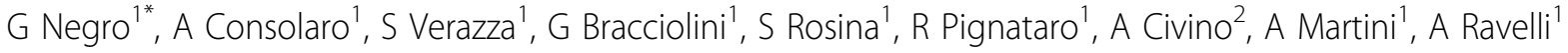 \\ From 20th Pediatric Rheumatology European Society (PReS) Congress \\ Ljubljana, Slovenia. 25-29 September 2013
}

\begin{abstract}
Introduction
The recent advances in the management of juvenile idiopathic arthritis (JIA) have increased considerably the potential to achieve disease remission or, at least, low levels of disease activity, and have consequently moved the therapeutic aims towards the attainment of inactive disease (ID). Complete disease quiescence is regarded as the ideal therapeutic target because its achievement helps preventing further joint damage and disability and may enhance physical function and quality of life.
\end{abstract}

\section{Objectives}

These issues have led to suggest that a tight control approach should be adopted in the management of JIA. We describe our experience with treat-to-target strategy.

\section{Methods}

Starting in March 2007, a treat-to-target approach to the management of all children with JIA first seen in the senior author's clinic was implemented, setting achievement of ID as primary goal and of minimal disease activity (MDA) or parent-acceptable symptom state (PASS) as secondary goals. In case primary goal was not reached, treatment was intensified as deemed necessary. Patient records were reviewed to evaluate the frequency of achievement of the therapeutic goals at $6,12,18$ and 24 months following initial evaluation. ID, MDA and PASS were defined according to both established criteria and Juvenile Arthritis Disease Activity Score (JADAS) cutoffs. The outcome of patients who achieved or did not achieve ID at last follow-up visit was compared by means of the
Juvenile Arthritis Functionality Scale (JAFS) and the Pediatric Rheumatology Quality of Life scale (PRQL).

\section{Results}

A total of 175 patients (77.7\% females) were enrolled. The most common ILAR subtypes were persistent oligoarthritis (53.1\%), extended oligoarthritis (14.9\%), and RF-negative polyarthritis (14.3\%); $3.4 \%$ of patients had systemic arthritis. The median age at disease onset was 2.8 years. At baseline visit, the median age was 3.5 years and the median disease duration was 0.2 years. Initial therapeutic interventions included intra-articular corticosteroid injection $(84 \%)$, methotrexate $(28 \%)$, systemic corticosteroids $(5.7 \%)$, and biologic medications (1.1\%). The frequency of achievement of treatment goals at study endpoints is shown in the table. At last follow-up visit, patients who had achieved ID had better functional ability $(\mathrm{p}=0.007)$ and physical well-being $(\mathrm{p}=0.007)$ than those who did not. The frequency of clinical remission on medication was $29.2 \%$. (Table 1 )

\section{Conclusion}

At 2 years after initial visit, a substantial percentage of patients had reached the states of ID or MDA or were in PASS. Patients who achieved ID had better physical function and well-being than those who did not. These findings suggest that the implementation of a treat-to-target approach may help improve patient outcomes.

\section{Disclosure of interest}

None declared.

${ }^{1}$ IRCCS G.Gaslini, Genova, Italy

Full list of author information is available at the end of the article 
Table 1

\begin{tabular}{|c|c|c|c|c|c|c|}
\hline & $\begin{array}{c}\text { Inactive } \\
\text { disease (ID) }\end{array}$ & $\begin{array}{l}\text { Minimal disease } \\
\text { activity (MDA) }\end{array}$ & $\begin{array}{c}\text { Parent-acceptable symptom } \\
\text { state (PASS) }\end{array}$ & $\begin{array}{c}\text { JADAS10 } \leq \\
1 \text { (ID) }\end{array}$ & $\begin{array}{c}\text { JADAS10 } \leq 2 / 3.8 \\
\text { (MDA) }\end{array}$ & $\begin{array}{c}\text { JADAS10 } \leq 3.5 / 5.4 \\
\text { (PASS) }\end{array}$ \\
\hline $\begin{array}{l}6 \text { months } \\
\mathrm{N}(\%)\end{array}$ & $50(35.2)$ & $62(43.7)$ & $76(66.1)$ & $43(31.6)$ & $43(31.6)$ & $64(47.1)$ \\
\hline $\begin{array}{l}12 \text { months } \\
\mathrm{N}(\%)\end{array}$ & $48(41)$ & $71(60.7)$ & $77(74.8)$ & $46(41.4)$ & $58(52.3)$ & $66(59.5)$ \\
\hline $\begin{array}{l}18 \text { months } \\
\mathrm{N}(\%)\end{array}$ & $46(47.4)$ & $60(61.9)$ & $69(82.1)$ & $43(46.2)$ & $60(64.5)$ & $67(72)$ \\
\hline $\begin{array}{l}24 \text { months } \\
\mathrm{N}(\%)\end{array}$ & $45(50.6)$ & $5(59.6)$ & $53(70.7)$ & $33(39.3)$ & $40(47.6)$ & $52(61.9)$ \\
\hline
\end{tabular}

\section{Authors' details}

${ }^{1}$ IRCCS G.Gaslini, Genova, Italy. ${ }^{2}$ Azienda Ospedaliera Card. Panico, Tricase,

Italy.

Published: 5 December 2013

doi:10.1186/1546-0096-11-S2-P155

Cite this article as: Negro et al:: PReS-FINAL-2143: Treat-to-target strategy

in juvenile idiopathic arthritis: experience in 175 newly-diagnosed

patients. Pediatric Rheumatology 2013 11(Suppl 2):P155.

Submit your next manuscript to BioMed Central and take full advantage of:

- Convenient online submission

- Thorough peer review

- No space constraints or color figure charges

- Immediate publication on acceptance

- Inclusion in PubMed, CAS, Scopus and Google Scholar

- Research which is freely available for redistribution

Submit your manuscript at www.biomedcentral.com/submit
C Biomed Central 